\title{
Three New Iridoid Glycosides from the Aerial Parts of Asperula involucrata
}

\author{
Hasan Kırmızıbekmez, ${ }^{* a}$ Kubilay Tiftik, ${ }^{\text {b }}$ Norbert Kúsz, ${ }^{c}$ Orsolya Orban-Gyapai, ${ }^{c}$ \\ Zoltán Péter Zomborszki, ${ }^{c}$ and Judit Hohmann ${ }^{c, d}$ \\ aDepartment of Pharmacognosy, Faculty of Pharmacy, Yeditepe University, TR-34755, Kayışdağı, i̇stanbul, Turkey, \\ e-mail: hasankbekmez@yahoo.com \\ ${ }^{\mathrm{b}}$ Faculty of Pharmacy, Yeditepe University, TR-34755 Kayışdağı, İstanbul, Turkey \\ 'Institute of Pharmacognosy, University of Szeged, Eötvös u 6, H-6720 Szeged, Hungary \\ dinterdisciplinary Centre of Natural Products, University of Szeged, Eötvös u. 6., H-6720 Szeged, Hungary
}

\begin{abstract}
Three new iridoid glycosides, named involucratosides $\mathrm{A}-\mathrm{C}(\mathbf{1}-\mathbf{3})$, were isolated from the $\mathrm{H}_{2} \mathrm{O}$ subextract of crude $\mathrm{MeOH}$ extract prepared from the aerial parts of Asperula involucrata along with a known iridoid glycoside (adoxoside), three flavone glycosides (apigenin 7-O- $\beta$-glucopyranoside, luteolin 7-O- $\beta$-glucopyranoside, apigenin 7-Orutinoside) as well as two phenolic acid derivatives (chlorogenic acid and ferulic acid 4-O- $\beta$-glucopyranoside). Their chemical structures were established by UV, IR, 1D- $\left({ }^{1} \mathrm{H},{ }^{13} \mathrm{C}\right.$ and JMOD) and 2D- (COSY, HSQC, HMBC and NOESY) NMR experiments and HR-ESI-MS. In addition, the crude extract, subextracts and isolates were evaluated for their xanthine oxidase inhibitory and antioxidant activities in in vitro tests. This is the first report on the chemical composition and bioactivities of $A$. involucrata.
\end{abstract}

Keywords: Asperula involucrata, Rubiaceae, Iridoid glycosides, Involucratosides A - C, Xanthine oxidase inhibitory activities, Antioxidant activities.

\section{Introduction}

The genus Asperula L. belongs to Rubiaceae family and contains around 200 species distributed worldwide. It is represented by 41 species in the flora of Turkey with an endemism rate of $49 \% .{ }^{[1]}$ Asperula involucrata WAHLENB. is a perennial herb mainly distributed in the northern parts of Turkey. ${ }^{[2]}$ Some Asperula species are utilized as diuretic, tonic, antidiarrheal agents as well as to reduce blood pressure and inflammation in several traditional medicines. ${ }^{[3][4]}$ Previous phytochemical studies on the genus Asperula revealed the presence of iridoids, flavonoids, anthraquinones and phenolic acids. ${ }^{[5-7]}$ In our previous study, we reported the isolation of new flavonoid and iridoid glycosides from $A$. lilaciflora. ${ }^{[8]}$ In the continuation of our researches on the isolation of new bioactive compounds from Asperula species growing in Turkey, we have investigated the secondary metabolites of A. involucrata which has not been previously investigated in terms of its phytochemical profile and biological activities. Herein we report the isolation and structure elucidation of nine compounds including three new iridoid glycosides $(\mathbf{1}-\mathbf{3})$. Further, xanthine oxidase inhibitory and DPPH free radical scavenging activities of the crude extract, subextracts and isolates were evaluated in in vitro tests as some flavonoids and iridoid glucosides were previously reported to be the potential inhibitors of xanthine oxidase enzyme. ${ }^{[9][10]}$

\section{Results and Discussion}

\section{Structure Elucidation}

The aerial parts of $A$. involucrata were extracted with $\mathrm{MeOH}$. The crude $\mathrm{MeOH}$ extract was dispersed in $\mathrm{H}_{2} \mathrm{O}$ and submitted to liquid-liquid extraction with $\mathrm{CHCl}_{3}$ to yield $\mathrm{H}_{2} \mathrm{O}$ and $\mathrm{CHCl}_{3}$ subextracts. The $\mathrm{H}_{2} \mathrm{O}$ subextract was subjected to various column chromatography protocols to afford three new compounds $(\mathbf{1}-\mathbf{3})$ along with six known ones (4-9) (Fig. 1).

Compound $\mathbf{1}$ was obtained as colorless amorphous powder. The molecular formula, $\mathrm{C}_{27} \mathrm{H}_{34} \mathrm{O}_{13}$, was assigned by HR-ESI-MS ( $\mathrm{m} / z 589.1905\left([\mathrm{M}+\mathrm{Na}]^{+}\right)$, calc. $\mathrm{C}_{27} \mathrm{H}_{34} \mathrm{NaO}_{13}$ 589.1897) and from the ${ }^{13} \mathrm{C}-\mathrm{NMR}$ data. The UV spectrum of $\mathbf{1}$ contained a maximum at $221 \mathrm{~nm}$ typical for C(4) substituted iridoids and its IR spectrum displayed absorption bands due to hydroxy groups at 3402, ester carbonyl group at 1701, 


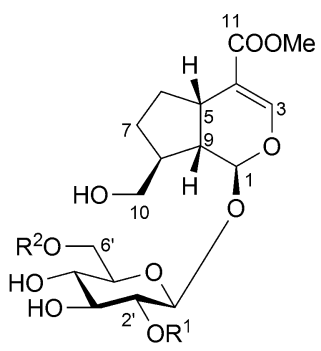

$1 \mathrm{R}^{1}=\mathrm{H}, \mathrm{R}^{2}=(E)$-Isoferuloyl $2 \mathrm{R}^{1}=(E)$-Cinnamoyl, $\mathrm{R}^{2}=\mathrm{H}$ $3 \mathrm{R}^{1}=(Z)-$ Cinnamoyl, $\mathrm{R}^{2}=\mathrm{H}$ $4 \mathrm{R}^{1}=\mathrm{H}, \mathrm{R}^{2}=\mathrm{H}$<smiles>O=C(/C=C/c1ccc(O)c(O)c1)O[C@@H]1C[C@](O)(C(=O)O)C[C@H](O)[C@H]1O</smiles><smiles>[R2]CCC(O)C(O)C(O)Oc1cc(O)c2c(=O)cc(-c3ccc(O)c([R1])c3)oc2c1</smiles>

$5 \mathrm{R}^{1}=\mathrm{H}, \mathrm{R}^{2}=\mathrm{H}$

$6 \mathrm{R}^{1}=\mathrm{OH}, \mathrm{R}^{2}=\mathrm{H}$

$7 \mathrm{R}^{1}=\mathrm{H}, \mathrm{R}^{2}=\alpha$ - Rha

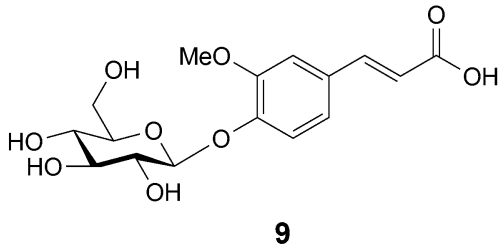

Figure 1. Structures of compounds (1 - 9) from Asperula involucrata.

conjugated $\mathrm{C}=\mathrm{C}$ at 1632 , and an aromatic ring at 1512 and $1440 \mathrm{~cm}^{-1}$. The ${ }^{1} \mathrm{H}-\mathrm{NMR}$ spectrum (Table 1) of 1 contained an olefinic signal at $\delta(\mathrm{H}) 7.44(\mathrm{~s})$, along with one hemiacetal signal at $\delta(\mathrm{H}) 5.02(d, J=7.3 \mathrm{~Hz})$, one oxymethylene at $\delta(\mathrm{H}) 3.52(d d, J=10.7,6.1 \mathrm{~Hz})$ and $3.48(d d, J=10.7,6.6 \mathrm{~Hz})$, three methine signals at $\delta(\mathrm{H}) 2.74-2.78(\mathrm{~m}), 2.10-2.15(\mathrm{~m})$ and $1.90-1.94$ $(m)$, two non-equivalent methylene signals at $\delta(\mathrm{H})$ $2.06-2.10(\mathrm{~m}), 1.24-1.30(\mathrm{~m})$ and $\delta(\mathrm{H}) 1.75-1.81$ $(m), 1.32-1.39(m)$ which were observed in the same spin system in COSY spectrum (Fig. 2). Moreover, the ${ }^{1} \mathrm{H}$-NMR spectrum also displayed an anomeric signal at $\delta(\mathrm{H}) 4.69(d, J=7.9)$ arising from a $\beta$-glucopyranose and a carboxymethyl singlet at $\delta(\mathrm{H}) 3.66(\mathrm{~s})$. These findings, taken together with the corresponding ${ }^{13} \mathrm{C}$-NMR data (Table 2) revealed that $\mathbf{1}$ is an adoxoside type iridoid glycoside. ${ }^{[1]}$ However, ${ }^{1} \mathrm{H}-\mathrm{NMR}$ spectrum of 1 exhibited additional signals; a pair of trans-coupled olefinic signals at $\delta(\mathrm{H}) 7.57$ and 6.32 (each $d, J=15.8$ ) as well as three aromatic signals at $\delta(\mathrm{H}) 7.05(d, J=1.9 \mathrm{~Hz}), 7.03(d d, J=8.4,1.9 \mathrm{~Hz})$ and $6.93(d, J=8.4 \mathrm{~Hz})$ as an $A B X$ system indicating the presence of a $(E)$-caffeoyl derivative in $1 .{ }^{13} \mathrm{C}-\mathrm{NMR}$ spectrum of 1 contained 27 resonances, eleven of which were assigned to iridoid aglycone while six were attributed to $\beta$-glucopyranose, the remaining ten signals $(\delta(C)$ 168.8, 151.6, 148.0, 146.8, 128.8, 122.8, $115.8,114.7,112.5,56.4)$ were characteristic for a trans-isoferuloyl moiety. ${ }^{[12]}$ The chemical shift values of $\mathrm{CH}_{2}\left(6^{\prime}\right)$ signals $(\delta(\mathrm{H}) 4.47$ and 4.42$)$ of $\beta$-glucopyranose unit were shifted downfield around 0.5 and $0.7 \mathrm{ppm}$ in the ${ }^{1} \mathrm{H}-\mathrm{NMR}$ spectrum of $\mathbf{1}$ indicating the esterification site of $(E)$-isoferuloyl unit to be $C\left(6^{\prime}\right)-\mathrm{OH}$ of $\beta$-glucopyranose. HMBC spectrum (Fig. 2) confirmed this assumption by the long-range coupling of carbonyl carbon $(\delta(C)$ 168.8) of $(E)$-isoferuloyl unit with the $\mathrm{CH}_{2}\left(6^{\prime}\right)$ of $\beta$-glucopyranose unit. Further key crosspeaks were evident between $C\left(4^{\prime \prime}\right)(\delta(C)$ 151.6) and methoxy signal at $\delta(\mathrm{H}) 3.89$ and between $\mathrm{C}(11)(\delta(\mathrm{C})$ 169.5) and methoxy signal at $\delta(\mathrm{H}) 3.66$ establishing the locations of methoxy groups. The relative configuration of the molecule was elucidated as depicted by the NOE interactions of $\mathrm{H}-\mathrm{C}(1)(\delta(\mathrm{H}) 5.02) / \mathrm{H}-\mathrm{C}(8)(\delta(\mathrm{H})$ 2.13) and $\mathrm{H}-\mathrm{C}(5)(\delta(\mathrm{H}) 2.76) / \mathrm{H}-\mathrm{C}(9)(\delta(\mathrm{H})$ 1.92) in the NOESY spectrum. Furthermore, the ${ }^{13} \mathrm{C}-\mathrm{NMR}$ data of the cyclopentan ring were compared to those of $C(8)$ epimeric iridoids, 8 - $\alpha$-dihydrogeniposide and 8 - $\beta$-dihydrogeniposide (adoxoside). ${ }^{[1]}$ The ${ }^{13} \mathrm{C}$ data of the aforementioned signals particularly $\mathrm{C}(7)(\delta(\mathrm{C}) 28.3), \mathrm{C}$ (8) $(\delta(C) 44.2)$ and $C(10)(\delta(C) 66.3)$ were found to be superimposable with those of adoxoside and showed significant differences from those of 8 - $\alpha$-dihydrogeniposide. These data suggested that 1 is the $6^{\prime}-O-(E)$ isoferuloyl ester of adoxoside and named as involucratoside A.

Compound $\mathbf{2}$ was obtained as colorless amorphous powder. The molecular formula was determined to be $\mathrm{C}_{26} \mathrm{H}_{32} \mathrm{O}_{11}$ by its HR-ESI-MS $(\mathrm{m} / \mathrm{z}$ $543.1857\left([\mathrm{M}+\mathrm{Na}]^{+}\right)$, calc. $\left.\mathrm{C}_{26} \mathrm{H}_{32} \mathrm{NaO}_{11}, \quad 543.1842\right)$ and ${ }^{13} \mathrm{C}$-NMR data. The UV and IR spectra were typical for an ester iridoid. Its ${ }^{1} \mathrm{H}$ - and ${ }^{13} \mathrm{C}-\mathrm{NMR}$ spectra (Tables 1 and 2) of $\mathbf{2}$ showed characteristic signals for adoxoside skeleton and were in good agreement with those of $\mathbf{1}$. The only difference was due to the 
Table 1. ${ }^{1} \mathrm{H}-\mathrm{NMR}\left(\mathrm{CD}_{3} \mathrm{OD}, 500 \mathrm{MHz}\right)$ data of compounds $\mathbf{1}-\mathbf{3} . \delta$ in ppm, $J$ in $\mathrm{Hz}$.

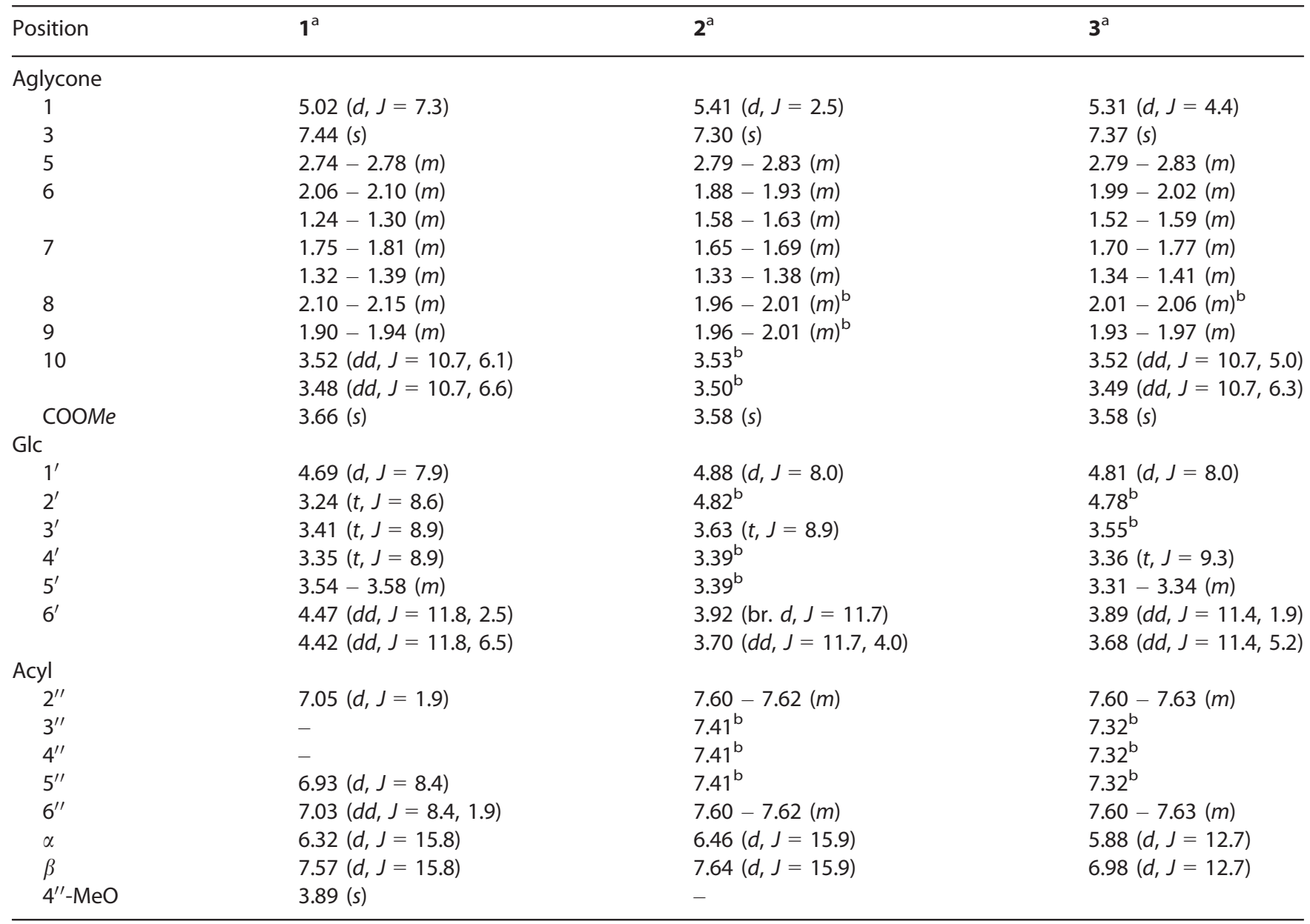

${ }^{a}$ Assignments are based on COSY, HSQC and HMBC experiments. ${ }^{b}$ Overlapped signals.
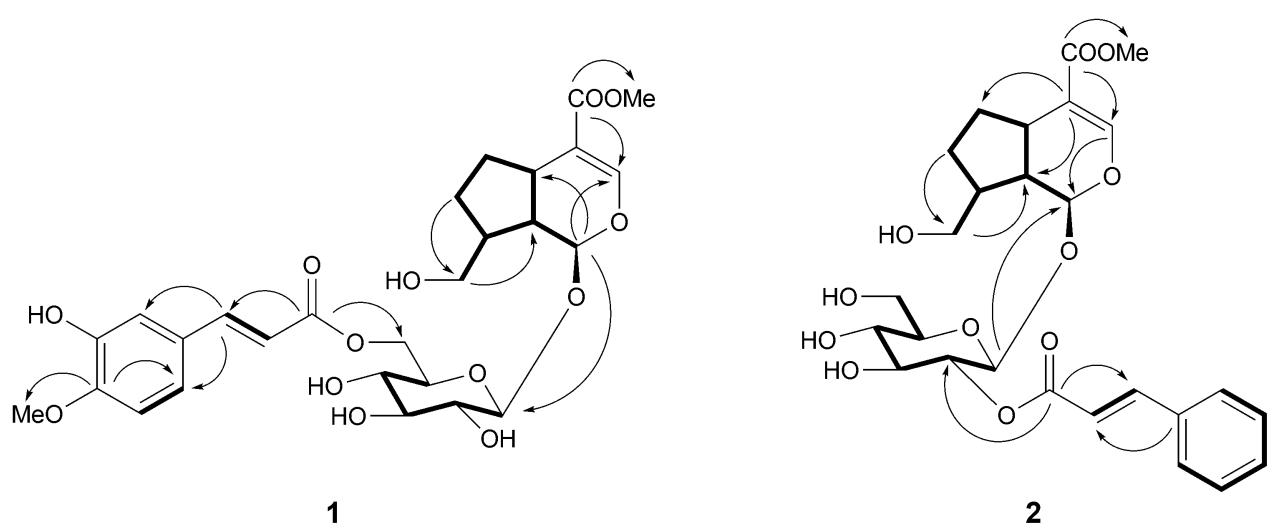

Figure 2. ${ }^{1} \mathrm{H},{ }^{1} \mathrm{H}-\mathrm{COSY}$ (bold lines) and key $\mathrm{HMBCs}(\mathrm{C} \rightarrow \mathrm{H}$, arrows) for compounds 1 and 2.

aromatic acyl group signals. The ${ }^{1} \mathrm{H}-\mathrm{NMR}$ spectrum of 2 exhibited characteristic signals for a (E)-cinnamoyl unit at $\delta(\mathrm{H}) 7.64$ and 6.46 (each $d, J=15.9$ ) as an $A X$ type and five aromatic signals at $\delta(\mathrm{H}) 7.60-$ $7.62(m, 2 \mathrm{H})$ and $7.41(3 \mathrm{H})$. These findings revealed that 2 contains $(E)$-cinnamoyl unit in its structure instead of (E)-isoferuloyl unit. The linkage of the (E)-cinnamoyl group was determined to be $C$ $\left(2^{\prime}\right)-\mathrm{OH}$ of $\beta$-glucopyranose on the basis of the downfield shift for $\mathrm{H}-\mathrm{C}\left(2^{\prime}\right)(\delta(\mathrm{H}) 4.82)$ of $\beta$-glucopyranose as well as the HMBC correlation between carbonyl carbon $(\delta(C)$ 167.4) of $(E)$-cinnamoyl unit with 
Table 2. ${ }^{13} \mathrm{C}-\mathrm{NMR}\left(\mathrm{CD}_{3} \mathrm{OD}, 125 \mathrm{MHz}\right)$ data of compounds $\mathbf{1}$ - 3. $\delta$ in ppm.

\begin{tabular}{|c|c|c|c|}
\hline Position & $1^{a}$ & $2^{a}$ & $3^{a}$ \\
\hline \multicolumn{4}{|l|}{ Aglycone } \\
\hline 1 & 98.7 & 97.0 & 97.7 \\
\hline 3 & 153.4 & 152.2 & 152.6 \\
\hline 4 & 112.0 & 112.7 & 112.7 \\
\hline 5 & 36.6 & 34.6 & 35.2 \\
\hline 6 & 33.8 & 31.3 & 32.1 \\
\hline 7 & 28.3 & 27.7 & 28.1 \\
\hline 8 & 44.2 & 43.4 & 43.8 \\
\hline 9 & 43.8 & 45.7 & 45.2 \\
\hline 10 & 66.3 & 66.4 & 66.4 \\
\hline 11 & 169.5 & 168.9 & 169.2 \\
\hline COOMe & 51.6 & 51.3 & 51.6 \\
\hline \multicolumn{4}{|l|}{ Glc } \\
\hline $1^{\prime}$ & 100.6 & 97.9 & 98.2 \\
\hline $2^{\prime}$ & 74.6 & 74.9 & 74.6 \\
\hline $3^{\prime}$ & 77.8 & 75.8 & 75.8 \\
\hline $4^{\prime}$ & 71.8 & 71.6 & 71.6 \\
\hline $5^{\prime}$ & 75.7 & 78.5 & 78.5 \\
\hline $6^{\prime}$ & 64.4 & 62.6 & 62.6 \\
\hline \multicolumn{4}{|l|}{ Acyl } \\
\hline $1^{\prime \prime}$ & 128.8 & 135.8 & 136.2 \\
\hline $2^{\prime \prime}$ & 114.7 & 130.8 & 131.2 \\
\hline $3^{\prime \prime}$ & 148.0 & 129.4 & 128.9 \\
\hline $4^{\prime \prime}$ & 151.6 & 131.5 & 130.1 \\
\hline $5^{\prime \prime}$ & 112.5 & 129.4 & 128.9 \\
\hline $6^{\prime \prime}$ & 122.8 & 130.0 & 131.2 \\
\hline$\alpha$ & 115.8 & 118.6 & 120.0 \\
\hline$\beta$ & 146.8 & 146.3 & 145.0 \\
\hline $\mathrm{CO}$ & 168.8 & 167.4 & 166.5 \\
\hline $4^{\prime \prime}-\mathrm{MeO}$ & 56.4 & - & - \\
\hline
\end{tabular}

${ }^{\text {a }}$ Assignments are based on COSY, HSQC and HMBC experiments.

the $\mathrm{H}-\mathrm{C}\left(2^{\prime}\right)$ of $\beta$-glucopyranose group. The NOE correlations for the iridoid aglycone were consistent with those of $\mathbf{1}$. Thus, the structure of $\mathbf{2}$ was deduced as $2^{\prime}-O-(E)$-cinnamoyl ester of adoxoside and named as involucratoside $B$.

Compound $\mathbf{3}$ was obtained as colorless amorphous powder. It had the same molecular formula $\mathrm{C}_{26} \mathrm{H}_{32} \mathrm{O}_{11}$ as 2, determined by its HR-ESI-MS $(\mathrm{m} / \mathrm{z}$ $543.1848\left([\mathrm{M}+\mathrm{Na}]^{+}\right)$, calc. $\left.\mathrm{C}_{26} \mathrm{H}_{32} \mathrm{NaO}_{11}, \quad 543.1842\right)$ and ${ }^{13} \mathrm{C}$-NMR data. Its NMR data were very similar to those of 2, except for the chemical shift values for olefinic protons $(\delta(\mathrm{H}) 6.98$ and 5.88) of the cinnamoyl unit which were shifted upfield. This finding along with the relatively small coupling constant $(J)$ values (each $12.7 \mathrm{~Hz}$ ) of these olefinic signals implied that the double bond geometry of cinnamoyl unit was (Z). The other NMR findings including HMBC and NOESY spectra for $\mathbf{3}$ were identical with those of $\mathbf{2}$. Accordingly, $\mathbf{3}$ was established as
$2^{\prime}-O$-(Z)-cinnamoyl ester of adoxoside and named as involucratoside $C$.

The known compounds were characterized as adoxoside (4), ${ }^{[11]}$ apigenin $7-O-\beta$-glucopyranoside (5), luteolin 7-O- $\beta$-glucopyranoside (6), apigenin 7-O-rutinoside (7) ${ }^{[13]}$ chlorogenic acid $(\mathbf{8}){ }^{[14]}$ and ferulic acid 4-O- $\beta$-glucopyranoside $(9){ }^{[15]}$ by comparison of their NMR data with those of published values.

The new iridoid glycosides obtained in this study are the esterified derivatives of adoxoside. Iridoid glycosides are regarded as significant chemotaxonomic markers particularly in dicotyledonous families and utilized for the chemotaxonomic evaluation of several genera and species. ${ }^{[16]}$ Adoxoside-type iridoid glycosides were previously reported from the genera Viburnum (Adoxaceae), ${ }^{[17]}$ Castilleja and Euphrasia (Orobanchaceae). ${ }^{[11]}$ They are also being reported for the first time in the genus Asperula. The occurrence of such iridoid glycosides in Asperula may contribute to the chemotaxonomy of the genus Asperula which is considered to be polyphyletic ${ }^{[18]}$ and may imply a relationship between Asperula and the genera Viburnum, Castilleja and Euphrasia.

\section{Biological Studies}

The crude extract, subextracts and isolates were evaluated for their xanthine oxidase inhibitory activities (Table 3). Only $\mathrm{H}_{2} \mathrm{O}$ subextract displayed weak xanthine oxidase inhibitory with $I C_{50}$ of $137.3 \mu \mathrm{g} / \mathrm{ml}$, while none of the compounds isolated thereof were found to be active. Although some flavonoids were previously reported as xanthine oxidase inhibitory agents from several medicinal plants, the flavonoids obtained in this study didn't exert notable inhibitory activity against xanthine oxidase. The absence of the activity of the tested flavonoids might be due to their glycosidic structures, as the flavonoid aglycones such as apigenin, luteolin, chrysoeriol, diosmetin, hispidulin, eupatilin, kaempferol and quercetin were found to inhibit the xanthine oxidase enzyme significantly. ${ }^{[10]}$ [19][20] Hence, it can be concluded that the glycosidation or an increase in the polarity of the flavonoids may lead to a decrease or loss in their xanthine oxidase inhibitory activity. The same samples were also tested for their antioxidant activities by DPPH method (Table 3). Among the extracts, crude $\mathrm{MeOH}$ extract and $\mathrm{H}_{2} \mathrm{O}$ subextract displayed activity with $I C_{50}$ values of 43.6 and $37.7 \mu \mathrm{g} / \mathrm{ml}$. Regarding the isolates, only phenolic compounds showed moderate DPPH free radical scavenging activities with $I C_{50}$ values ranging from 3.6 to $26.8 \mu \mathrm{g} / \mathrm{ml}$. 
Table 3. In vitro xanthine oxidase (XO) inhibitory and antioxidant activities of extract, subextracts and isolates (1 - 9) from Asperula involucrata

\begin{tabular}{lcc}
\hline Sample & $\begin{array}{l}\text { XO-Inhibitory } \\
\text { activity }\left(I C_{50},\right. \\
\mu \mathrm{g} / \mathrm{ml} \pm \mathrm{SD})\end{array}$ & $\begin{array}{l}\text { Antioxidant } \\
\text { activity } \\
\left(I C_{50}, \mu \mathrm{g} / \mathrm{ml} \pm \mathrm{SD}\right)\end{array}$ \\
\hline MeOH extract & $186.9 \pm 47.4$ & $43.6 \pm 0.90$ \\
$\mathrm{H}_{2} \mathrm{O}$ subextract & $137.3 \pm 32.7$ & $37.7 \pm 0.13$ \\
$\mathrm{CHCl}_{3}$ subextract & $356.5 \pm 37.1$ & $\mathrm{NA}$ \\
$\mathbf{1}-\mathbf{3}, \mathbf{5}$ & $\mathrm{NA}$ & $\mathrm{NA}$ \\
$\mathbf{4}$ & $\mathrm{NA}$ & $26.8 \pm 2.19$ \\
$\mathbf{6}$ & $\mathrm{NA}$ & $19.9 \pm 0.89$ \\
$\mathbf{7}$ & $\mathrm{NA}$ & $10.4 \pm 0.10$ \\
$\mathbf{8}$ & $\mathrm{NA}$ & $3.60 \pm 0.15$ \\
$\mathbf{9}$ & $\mathrm{NA}$ & $20.4 \pm 0.52$ \\
Ascorbic acid & & $0.60 \pm 0.13$ \\
Allopurinol & $7.5 \pm 0.1 \mu \mathrm{M}$ & \\
\hline
\end{tabular}

NA, not active.

\section{Experimental Section}

General

TLC: Precoated $\mathrm{SiO}_{2} 60 \mathrm{~F}_{254}$ plates (Merck, Darmstadt, Germany); visualized under UV light and by spraying with $1 \%$ vanillin/ $\mathrm{H}_{2} \mathrm{SO}_{4}$ soln., followed by heating at $105{ }^{\circ} \mathrm{C}$ for $2-3 \mathrm{~min}$. Column chromatography (CC): $\mathrm{SiO}_{2} 60$ (0.063 - 0.200 mm; Merck, Darmstadt), Polyamide (Sigma-Aldrich, St. Louis, MO, USA), and Sephadex LH-20 gel (Sigma-Aldrich, St. Louis, MO, USA). Mediumpressure liquid chromatography (MPLC): Sepacore ${ }^{\circledR}$ Flash Systems X10/X50 (Büchi Labortechnik AG, Flawil, Switzerland), Redi sep columns (LiChroprep $C_{18}, 130$ and $43 \mathrm{~g}, \mathrm{SiO}_{2} 12$ and $4 \mathrm{~g}$; Teledyne Isco, Lincoln, Nebraska, USA). Semiprep. HPLC: Waters 2487 (Waters, Milford, Massachusetts, USA). The reversed-phase HPLC column $\left(\mathrm{C}_{18}, 5 \mu \mathrm{m}, 250 \times 4 \mathrm{~mm}\right.$ i.d., Merck, Darmstadt, Germany). Optical rotations: PerkinElmer 341 polarimeter (PerkinElmer, Waltham, Massachusetts, USA). UV Spectra: HP Agilent 8453 spectrophotometer (Agilent Techonologies, Santa Clara, CA, USA); $\lambda_{\max }$ in $\mathrm{nm}$. IR Spectra (KBr): PerkinElmer 2000 FT-IR spectrometer (PerkinElmer, Waltham, Massachusetts, USA); $v$ in $\mathrm{cm}^{-1}$. NMR Spectra: Bruker Avance DRX 500 instrument (Billerica, MA, USA; $500\left({ }^{1} \mathrm{H}\right)$ and $\left.125 \mathrm{MHz}\left({ }^{13} \mathrm{C}\right)\right)$ in $\mathrm{CD}_{3} \mathrm{OD} ; \delta$ in ppm rel. to $\mathrm{Me}_{4} \mathrm{Si}$ as internal standard, $J$ in $\mathrm{Hz}$. HR-ESI-MS: $Q$ Exactive Orbitrap (Thermo Fisher Scientific, Waltham, MA, USA) in $\mathrm{MeOH}$; positive-ion mode; in $\mathrm{m} / \mathrm{z}$.

\section{Plant Material}

The aerial parts of Asperula involucrata WAHLENB. (Rubiaceae) were collected from Kayışdağı, İstanbul, in May 2015. The plant material was authenticated by Dr.
Hasan Kırmızıbekmez. A voucher specimen (YEF 15007) has been deposited with the Herbarium of Faculty of Pharmacy, Yeditepe University, İstanbul.

\section{Extraction and Isolation}

The shade-dried and powdered aerial parts of $A$. involucrata $(100 \mathrm{~g})$ were extracted with $\mathrm{MeOH}$ for $2 \mathrm{~h}$ $(1.1 \mathrm{I} \times 2)$ at $45^{\circ} \mathrm{C}$. The combined $\mathrm{MeOH}$ extracts were concentrated under vacuum to yield a crude extract $(27 \mathrm{~g})$ which was suspended in $\mathrm{H}_{2} \mathrm{O}(40 \mathrm{ml})$ and partitioned with $\mathrm{CHCl}_{3}(3 \times 40 \mathrm{ml})$ to obtain $\mathrm{H}_{2} \mathrm{O}$ $(16.3 \mathrm{~g})$ and $\mathrm{CHCl}_{3}(7.1 \mathrm{~g})$ subextracts. The $\mathrm{H}_{2} \mathrm{O}$ subextract was fractionated over Polyamide column $(75 \mathrm{~g}$, $3.3 \times 62 \mathrm{~cm}$ ) eluting with a gradient solvent system $\mathrm{H}_{2} \mathrm{O} / \mathrm{MeOH}(100: 0-0: 100)$ to give six main fractions, Frs. A - F. Fr. B (282 mg) was subjected to $\mathrm{C}_{18}$-Medium Pressure Liquid Chromatography (LiChroprep $\mathrm{C}_{18}$-MPLC, $43 \mathrm{~g}$ ) eluting with stepwise $\mathrm{H}_{2} \mathrm{O} / \mathrm{MeOH}$ gradient $(95: 5 \rightarrow 20: 80)$ to give ferulic acid 4-O- $\beta$-glucopyranoside $(\mathbf{9}, 2 \mathrm{mg})$. Fr. $D$ (656 $\mathrm{mg}$ ) was submitted to $\mathrm{C}_{18}$-MPLC $(130 \mathrm{~g})$ eluting with $\mathrm{H}_{2} \mathrm{O} / \mathrm{MeOH}$ gradient $(90: 10 \rightarrow 0: 100)$ to yield eight main fractions, Frs. $D_{1}-D_{8}$. Rechromatography of Fr. $D_{2}(35 \mathrm{mg})$ by Sephadex LH-20 CC $(6 \mathrm{~g}, 1.3 \times 26 \mathrm{~cm})$ eluting with $\mathrm{MeOH}$ gave apigenin 7-O-rutinoside $(7,3 \mathrm{mg})$. Fr. $D_{4}$ (70 mg) was applied to Medium Pressure Liquid Chromatography $\left(\mathrm{SiO}_{2}, 12 \mathrm{~g}\right)$ eluting with $\mathrm{CHCl}_{3} / \mathrm{MeOH}$ gradient (95:5 $\rightarrow$ 70:30) to obtain adoxoside $(\mathbf{4}, 3 \mathrm{mg})$. Fr. $D_{6}(50 \mathrm{mg})$ was chromatographed on $\mathrm{SiO}_{2}(7 \mathrm{~g}$, $1.3 \times 20 \mathrm{~cm}$ ) column using the gradient mixture of $\mathrm{CHCl}_{3} / \mathrm{MeOH}(100: 0 \rightarrow 92: 8)$ as mobile phase to afford involucratoside $A(\mathbf{1}, 8 \mathrm{mg})$. Similarly, separation of Fr. $D_{8}(113 \mathrm{mg})$ by $\mathrm{SiO}_{2}$ column chromatography using $\mathrm{CH}_{2} \mathrm{Cl}_{2} / \mathrm{MeOH} / \mathrm{H}_{2} \mathrm{O} \quad(100: 0: 0 \rightarrow$ 85:15:1) $\quad$ gradient yielded involucratoside $B(\mathbf{2}, 6 \mathrm{mg})$ along with a fraction (32 mg) containing impure 3. Purification of this fraction by $\mathrm{SiO}_{2}$-MPLC $(4 \mathrm{~g})$ using a gradient solvent system of $\mathrm{CHCl}_{3} / \mathrm{MeOH}(100: 0 \rightarrow 80: 20)$ gave involucratoside C (3, $3 \mathrm{mg})$. Fr. E (480 mg) was subjected to $\mathrm{C}_{18}$-MPLC (43 g) eluting with stepwise $\mathrm{H}_{2} \mathrm{O} / \mathrm{MeOH}$ gradient $(90: 10 \rightarrow 30: 70)$ to obtain chlorogenic acid (8, $20 \mathrm{mg}$ ). Fr. F (699 mg) was subjected to semi-preperative RP-HPLC $\left(\mathrm{MeOH} / \mathrm{H}_{2} \mathrm{O}\right.$ 35:65) to purify apigenin 7-O- $\beta$-glucopyranoside $(5,3 \mathrm{mg})$ and luteolin $7-O-\beta$ glucopyranoside $(6,2 \mathrm{mg})$.

Involucratoside A (= Methyl (1S,4aS,7S,7aS)-1,4a, $5,6,7,7$ a-Hexahydro-1-(\{6-O-[(2E)-3-(3-hydroxy4-methoxyphenyl)prop-2-enoyl]- $\beta$-D-glucopyranosyl\}oxy)-7-(hydroxymethyl)cyclopenta[c]pyran-4-carboxylate; 1). Amorphous powder. $[\alpha]_{\mathrm{D}}^{26}=-68 \quad(c=0.1$, $\mathrm{MeOH})$. UV (MeOH): 221, 239, 297 (sh), 326. IR (KBr): 3402, 2952, 1701, 1632, 1512, 1440. ' ${ }^{1} \mathrm{H}-\mathrm{NMR}$ : (Table 1). 
${ }^{13} \mathrm{C}-\mathrm{NMR} \quad$ (Table 2). $\quad$ HR-ESI-MS $\quad$ (pos.): 589.1905 $\left([\mathrm{M}+\mathrm{Na}]^{+}, \mathrm{C}_{27} \mathrm{H}_{34} \mathrm{NaO}_{13}{ }^{+}\right.$; calc. 589.1897).

Involucratoside B (= Methyl $(1 S, 4 a S, 7 S, 7 a S)$ 1,4a,5,6,7,7a-Hexahydro-7-(hydroxymethyl)-1-(\{2-0[(2E)-3-phenylprop-2-enoyl]- $\beta$-D-glucopyranosyl\}oxy)cyclopenta[c]pyran-4-carboxylate; 2). Amorphous powder. $[\alpha]_{\mathrm{D}}^{26}=-99(c=0.1, \mathrm{MeOH})$. UV $(\mathrm{MeOH}): 218$, 223, 278. IR (KBr): 3524, 2921, 1705, 1637, 1450. ${ }^{1} \mathrm{H}-$ NMR: (Table 1). ${ }^{13} \mathrm{C}-\mathrm{NMR}$ (Table 2). HR-ESI-MS (pos.): $543.1857\left([\mathrm{M}+\mathrm{Na}]^{+}, \mathrm{C}_{26} \mathrm{H}_{32} \mathrm{NaO}_{11}{ }^{+}\right.$; calc. 543.1842).

Involucratoside C (= Methyl (1S,4aS,7S,7aS)-1,4a, 5,6,7,7a-Hexahydro-7-(hydroxymethyl)-1-(\{2-O-[(2E)3-phenylprop-2-enoyl]- $\beta$-D-glucopyranosyl\}oxy)cyclopenta[c]pyran-4-carboxylate; 3). Amorphous powder. $[\alpha]_{\mathrm{D}}^{26}=-47(c=0.1, \mathrm{MeOH})$. UV (MeOH): 218, 223, 275. IR (KBr): 3432, 2917, 1733, 1708, 1632, 1437. ${ }^{1} \mathrm{H}-\mathrm{NMR}$ (500 MHz, CD ${ }_{3} \mathrm{OD}$ ) and ${ }^{13} \mathrm{C}-\mathrm{NMR}$ (125 MHz, CD $\mathrm{OD}$ ): see Tables 1 and 2. HR-ESI-MS: $543.1848\left([\mathrm{M}+\mathrm{Na}]^{+}\right.$, $\mathrm{C}_{26} \mathrm{H}_{32} \mathrm{NaO}_{11}{ }^{+}$; calc. 543.1842).

\section{Xanthine Oxidase Inhibitory Assay}

Xanthine oxidase isolated from bovine milk (lyophilized powder) and xanthine powder were purchased from Sigma-Aldrich. The production of uric acid by xanthine oxidase was measured at $290 \mathrm{~nm}$ for $3 \mathrm{~min}$ in 96-well plate, using the plate reader FluoSTAR OPTIMA (BMG LABTECH) Fluorescence, in a total volume of $300 \mu \mathrm{l}$ as described in the literature. ${ }^{[21]}$ Stock solutions were prepared as recommended: $50 \mathrm{~mm}$ potassium buffer, $\mathrm{pH} 7.5,0.15 \mathrm{~mm}$ xanthine solution, $\mathrm{pH} 7.5$ and $\mathrm{XO}$ enzyme 0.04 units $/ \mathrm{ml}$. The stock solutions of the extracts $(12 \mathrm{~g} / \mathrm{ml})$ were prepared in DMSO solution. $140 \mu \mathrm{l}$ of buffer solution and $100 \mu \mathrm{l}$ of xanthine solution were added to the wells, to give a final concentration of 33 and $0.05 \mathrm{~mm}$, resp. Extracts and compounds were added in appropriate volumes so that the final concentration of DMSO in the assay did not exceed $3.3 \%$ of the total volume. The reaction was initiated by automatic addition of $50 \mu \mathrm{l}$ of $\mathrm{XO}$ solution to a final concentration of 0.006 units $/ \mathrm{ml}$. Each sample was tested in triplicate. Allopurinol, the positive control, was tested in different concentrations, started from 10 to $0.3125 \mu \mathrm{g} / \mathrm{ml}$ in microdilution, to achieve the $I C_{50}$ value. The $I C_{50}$ values were calculated by analyzing the inhibitory percentage values of each concentration using GraphPad Prism 5.04 software (GraphPad Software Inc.) with nonlinear regression.

\section{Antioxidant Activity Assay}

The antioxidant activity of the extracts and pure compounds (isolates) were evaluated by using DPPH free radical scavenging method as described previously. ${ }^{[22]}$ Microdilution series were made on a 96 well microplate from the sample solutions $(1 \mathrm{mg} / \mathrm{ml}$, prepared with HPLC grade $\mathrm{MeOH}$ ) beginning from $100 \mu \mathrm{l}$, in three parallel copies. To each well $100 \mu$ of DPPH (2,2-diphenyl-1-picrylhydrazyl, Sigma-Aldrich, Germany) solution $(100 \mu \mathrm{m}$, dissolved in HPLC grade $\mathrm{MeOH})$ was added, to gain $200 \mu \mathrm{l}$ final volume. After $30 \mathrm{~min}$ of storing at r.t. in dark conditions, the absorbance was measured at $550 \mathrm{~nm}$ with a BMG Labtech FluoStar Optima plate reader. As positive control $0.1 \mathrm{mg} / \mathrm{ml}$ ascorbic acid solution was used. The evaluation of $E C_{50}$ values were carried out with the help of Graphpad Prism 6.05.

\section{Supplementary Material}

Supporting information for this article is available on the WWW under https://doi.org/10.1002/cbdv.201600288.

\section{Acknowledgements}

The authors thank to Attila Csorba (Department of Pharmacognosy, University of Szeged) for the HR-MS measurements.

\section{Conflict of Interest}

The authors declare no conflicts of interest.

\section{References}

[1] M. Öztürk, J. Bot. 2013, 37, 46.

[2] F. Ehrendorfer, E. Schönbeck-Temesy, in 'Flora of Turkey and East Aegean Islands', Ed. P. H. Davis, University Press, Edinburgh, 1982, Vol. 7, p. $734-767$.

[3] T. Baytop, 'Theraphy with Medicinal Plants in Turkey: Past and Present', Nobel Tıp Kitabevi, İstanbul, 1999, p. 371.

[4] M. R. Loizzoa, A. M. Saab, R. Tundis, F. Menichini, M. Bonesi, V. Piccolo, G. A. Statti, B. de Cindio, P. J. Houghton, F. Menichini, J. Ethnopharmacol. 2008, 119, 109.

[5] A. Park, H. J. Kim, J. S. Lee, E.-R. Woo, H. Park, Y. S. Lee, J. Nat. Prod. 2002, 65, 1363.

[6] U. Özgen, C. Kazaz, H. Secen, M. Coskun, Turk. J. Chem. 2006, 30, 15 .

[7] O. Tzakou, K. Lempesis, A. Loukis, Nat. Prod. Commun. 2011, 6, 237.

[8] H. Kırmızıbekmez, H. Bardakcı, M. Masullo, O. Kamburoglu, G. Eryılmaz, G. Akaydın, E. Yeşilada, S. Piacente, Helv. Chim. Acta 2014, 97, 1571.

[9] X. Ling, W. Bochu, Pharmazie 2014, 69, 243.

[10] Z. Hajdú, A. Martins, O. Orbán-Gyapai, P. Forgo, N. Jedlinszki, I. Máthé, J. Hohmann, Rec. Nat. Prod. 2014, 8, 299.

[11] C. A. Boros, F. R. Stermitz, J. Nat. Prod. 1990, 53, 1055.

[12] T. Miyase, A. Mimatsu, J. Nat. Prod. 1999, 62, 1079. 
[13] K. R. Markham, V. M. Chari, T. J. Mabry, in 'The Flavonoids: Advances in Research', Eds. J. B. Harborne and T. J. Mabry, Chapman \& Hall, London, 1982, p. 19 - 133.

[14] A. Cheminat, R. Zawatzky, H. Becker, R. Brouillard, Phytochemistry 1988, 27, 2787.

[15] B. Baderschneider, P. Winterhalter, J. Agric. Food Chem. 2001, 49, 2788.

[16] B. Dinda, S. Debnath, Y. Harigaya, Chem. Pharm. Bull. 2007, 55, 159.

[17] Y. Fukuyama, Y. Minoshima, Y. Kishimoto, I.-S. Chen, H. Takahashi, T. Esumi, J. Nat. Prod. 2004, 67, 1833.

[18] A. Natali, J. F. Manen, F. Ehrendorfer, Ann. Mo. Bot. Gard. 1995, 82, 428.
[19] M. T. T. Nguyen, S. Awale, Y. Tezuka, J.-Y. Ueda, Q. L. Tran, S. Kadota, Planta Med. 2006, 72, 46.

[20] D. A. Kostic, D. S. Dimitrijevic, G. S. Stojanovic, I. R. Palic, A. S. Dordevic, J. D. Ickovski, J. Chem. 2015, Article Number: 294858, DOI: 10.1155/2015/294858.

[21] O. Orbán-Gyapai, I. Lajter, J. Hohmann, G. Jakab, A. Vasas, Phytother. Res. 2015, 29, 459.

[22] Z. Hajdú, J. Hohmann, P. Forgo, T. Martinek, M. Dervarics, I. Zupkó, G. Falkay, D. Cossuta, I. Máthé, Phytother. Res. 2007, 21, 391.

Received August 12, 2016 Accepted October 28, 2016 